\title{
Some Preliminary Studies of Colletotrichum musae Associated with Banana Anthracnose Disease in Jaffna District, Sri Lanka
}

\author{
H. K. Rasangi Priyadarshanie, A.Vengadaramana*
}

Department of Botany, Faculty of Science, University of Jaffna, Sri Lanka

Copyright (C) 2015 by authors, all rights reserved. Authors agree that this article remains permanently open access under the terms of the Creative Commons Attribution License 4.0 International License

\begin{abstract}
Anthracnose caused by Colletotrichum species is a common postharvest disease of banana fruit in Sri Lanka. The present study was conducted to determine morphological and pathogenic variations and influence of culture media on the growth of Colletotrichum musae isolates, causing anthracnose disease of banana. Six colletotrichum musae isolates were isolated from 3 different banana local cultivars ('Kathali', 'Kappal', 'Etharai'). Length, width and length:width ratio of the spores differed significantly among 6 isolates of C.musae. Among the different media tested, Potato and Carrot dextrose agar media supported significantly the maximum growth of all the six isolates of $C$. musae. Recommended dosage of the fungicides Homai (Thiophanate-methyl 50\% + Thiram 30\% WP) and Topsin (Thiophanate-methyl 50\%) completely inhibited the mycelia growth of six isolates in vitro. Characteristic symptoms of anthracnose were started to develop by all the isolates of $C$. musae on banana variety 'kathali' 2 days after inoculation of the pathogen. The present study revealed that morphological and pathogenic variations exist among different isolates of $C$. musae infecting banana fruits in Jaffna district of Sri Lanka.
\end{abstract}

Keywords Postharvest Disease, Fungicide, Kathali, Kappal, Etharai, Culture Media, Pathogenic Variations

\section{Introduction}

Anthracnose is the most important post-harvest disease of Banana in Sri Lanka. Most of the commercial banana varieties grown in Sri Lanka are susceptible to anthracnose causing post harvest losses [2,14]. Anthracnose becomes severe when the banana fruits are wounded by scratches during handling and transportation, making the fruit unmarketable. It deteriorates the quality and nutritive value of the fruits and renders them unfit for marketing and consumption thereby causing severe loss to farmers and traders. Banana anthracnose caused by Colletotrichum musae (Berk. and Curt) Arx. is considered as one of the most important diseases of banana in the global level and is one of the major constraints to banana production [28]. The genus Colletotrichum and its teleomorph Glomerella are considered to be major plant pathogens worldwide [1]. They cause significant economic damage to crops in tropical, subtropical and temperate regions [3]. C. musae is the most important pathogen on wounded green and ripe banana fruits $[12,21]$. Symptoms of anthracnose include black and sunken lesions with spore masses or acervuli in the lesion [10]. This disease usually occurs during long transportation and storage period with relatively low temperature and high humidity [29]. C. musae has also been reported causing blossom end rot, crown rot and tip rot of banana [13]. Infection on the banana usually starts during the development of the fruit but remains quiescent until the fruit ripens; symptoms often manifest during storage and marketing [17]. Many banana cultivars in Sri Lanka are susceptible for the diseases caused by Colletotrichum spp.. It reproduces in asexual manner and generally the spores are colorless and oval shape. Differentiation between Colletotrichum species based on host range or host origin may not be reliable, since it infects broad range of host plants. Although C. musae is the most common species associated with anthracnose of banana, $C$. gloeosporioides has also been reported to be associated with banana anthracnose $[31,6]$. Simple morphological characteristics, such as conidial dimensions, appressorial dimensions, presence or absence of setae and perithecia and also growth rate have been widely used as taxonomic criteria within the genus Colletotrichum in the past [22]. The objective of this work was to determine the morphological and pathogenic variations among isolates of Colletotrichum musae isolated from three banana cultivars such as 'Kathali', 'Kappal' and 'Etharai' in Jaffna district of Sri Lanka and evaluate influence of culture media on the growth of mycelial growth. 


\section{Materials and Methods}

\section{Isolation of fungi}

Three banana cultivars (local names in Jaffna district: 'Katali', 'ethaeai' and 'kappal') with symptom of anthracnose were collected from Thirunelvely vegetable market in Jaffna district of Sri Lanka. Fungi were isolated from anthracnose lesion on three varieties of bananas sold in the market. The infected fruits which showed typical symptoms were surface sterilized in $10 \%$ Clorox solution for three minute and washed repeatedly thrice in sterile distilled water then air-dried on a clean bench. Then surface sterilized peel of fruits were cut into small bits measuring about $1 \mathrm{~cm}$ and transferred to sterile petri plates containing CPDA medium (Commercial Potato Dextrose agar) with streptomycin $100 \mu \mathrm{g} / \mathrm{mL}$ under asepic condition then incubated at room temperature. The fungal colonies that appeared on the banana peel bits after incubation period were isolated in fresh sterile CPDA medium with streptomycin $100 \mu \mathrm{g} / \mathrm{mL}$ and were purified and identified.

\section{Growth characteristics of Colletotrichum isolates in different media}

$5 \mathrm{~mm}$ discs of each fungus obtained from pure cultures were transferred at the centre of sterile Petri dishes (in triplicates) containing five different growth media e.g. (i) Commercial Potato Dextrose Agar (CPDA) [CPDA 39 g; Distilled $\mathrm{H}_{2} \mathrm{O}$ 1L] (ii) Potato Dextrose Agar (PDA) [Potato (peeled) $200 \mathrm{~g}$; Dextrose $20 \mathrm{~g}$; Agar $20 \mathrm{~g}$; Distilled water 1L] (iii) Carrot Dextrose Agar (CDA) [Carrot (peeled) $200 \mathrm{~g}$; Dextrose 20 g; Agar 20 g; Distilled water 1L] (iv) Onion Dextrose Agar (ODA) [Onion 200g; Agar 13 g; Distilled water 1 L] and (v) Tap water Dextrose Agar (TDA) [Dextrose 20g; Agar 20g; Tap water 1L). The Petri dishes of three replicates in each medium were then incubated for 6 days at $25 \pm 1^{\circ} \mathrm{C}$ at room temperature and macroscopic features (e.g. colour of the upper surface and reverse side, texture of colonies) of colony characters and rate of colony growth $(\mathrm{cm} /$ day) on each medium were recorded.

\section{Variation of spore morphology of Colletotrichum isolates}

Spore shapes and dimensions observed by light microscope were measured. Thirty spores from each fungal isolate were selected randomly and used to measure width and length by a calibrated ocular micrometer.

\section{Pathogenic variation}

In order to prove Koch's postulates pathogenic ability of the isolated fungi was performed under laboratory conditions. Fully matured green unripe banana fruits variety 'kathali' were collected from the field, washed thoroughly under running tap water. The fruits were surface sterilized with $10 \%$ Clorox solution for 3 minutes and rinsed with sterilized distilled water for three times. Surface disinfested fruits were air dried under a laminar air flow cabinet and used in pathogenicity trials. Spore suspension $\left(1 \times 10^{5}\right.$ spores $\left./ \mathrm{mL}\right)$ of the pathogens was prepared using a six days old PDA separately. Two wounds were made on banana fruit using cork-borer $(5 \mathrm{~mm}$ diameter) and filled with $20 \mu \mathrm{L}$ spore suspension. The fruits inoculated with sterile distilled water served as control. The inoculated fruit and control were covered with plastic and incubated at room temperature. The Banana fruits were arranged according to a completely randomized design (CRD) with six replicates. The fungus was re-isolated from the artificially inoculated fruits showing typical anthracnose symptoms and the culture obtained was confirmed for its morphology and colony characters.

\section{Sensitivity to Fungicide}

Homai (Thiophanate-methyl 50\% + Thiram 30\% WP) and Topsin (Thiophanate-methyl 50\%) fungicides recommended by the Department of Agriculture, Sri Lanka were used for in vitro assays. In the in vitro assay, recommended dosage of Homai $(1.8 \mathrm{~g} / \mathrm{L})$ and Topsin $(1.2 \mathrm{~g} / \mathrm{L})$ were dissolved in sterile distilled water, added to molten PDA medium supplemented with streptomycin $\left(100 \mu \mathrm{gmL}^{-1}\right)$ then mixed thoroughly by gentle shaking. From each isolate of Colletotrichum musae, a myclelial plug having diameter of $5 \mathrm{~mm}$ was placed separately on PDA medium supplemented with Homai and Topsinn incubated for six days at room temperature $(32 \pm$ $2^{\circ} \mathrm{C}$ ). Each fungal isolate was replicated three times. Controls were maintained for each isolate by placing a mycelial plug on PDA medium supplemented with the antibiotic but not containing the fungicide. Radial growth of the colony was measured for each isolate grown on PDA with and without the fungicide (control). Relative inhibition of colony growth (\%) was calculated for each isolate by using the growth data values measured after six days on control plates and plates amended with fungicides [9].

\section{Data analysis}

Data were analyzed by variance (ANOVA) using a SAS statistical package (version 9.1.3) and mean separation was done by Least Significance Difference (LSD).

\section{Results and Discussion}

\section{Variation of colony morphology}

Six Colletotrichum isolates were isolated from anthracnose infected banana fruits (2 isolates per each variety). Isolates $\mathrm{cm} 1 \& \mathrm{~cm} 2, \mathrm{~cm} 3 \& \mathrm{~cm} 4$ and $\mathrm{cm} 5 \& \mathrm{~cm} 6$ (Figure 1) were isolated from banana variety 'Kathali', 'Kappal' and 'Etharai' respectively. Identification of Colletotrichum isolates was based on morphological characters such as colony characters and size and shape of conidia according to descriptions of Sutton and Waterson [23], Lim et al.[11], Photita et al.[15] and Adb-Elsalam et al.[1].

\section{Growth characteristics of pathogen in different media}

The growth characters of $C$. musae isolates were studied on five different solid media. The colony growth rate and colony colour (upper and riverside) were considered as growth characters. All the six $C$. musae isolates produced 
very low dense colony in TDA medium and upper and lower surface were pale in colour. Hence TDA medium is not suitable for growth of C. musae. Colonies in CDA, CPDA, ODA and PDA showed difference in surface and reverse colouration of the six isolates was distinct in CPDA medium (whitish ash on surface and dark ash on reverse except isolate $\mathrm{cm} 2$ where the reverse side was light ash in colour) with PDA, ODA and CDA media (upper surface pinkish white in colour and lower surface light yellow) at 6 days after incubation at room temperature $\left(32 \pm 2^{\circ} \mathrm{C}\right)$. Growth rates showed a significant difference among six Colletotrichum isolates $(\mathrm{P}<0.0001)$ in different media at 6 days after incubation at room temperature $\left(32 \pm 2^{\circ} \mathrm{C}\right)$. There was no significant difference present among 6 isolates in CDA and PDA and these isolates exhibited a growth rate $>1.4 \mathrm{~cm} /$ day. All six Colletotrichum isolates in CDA and PDA media and isolates $\mathrm{cm} 1, \mathrm{~cm} 3$ and $\mathrm{cm} 6$ in ODA medium showed highest growth (Figure 2). The lowest growth rate was shown by isolate $\mathrm{cm} 3$ in CPDA medium. Type of culture media and their chemical compositions significantly affected the mycelia growth rate and conidial production of Phoma exigua [32].

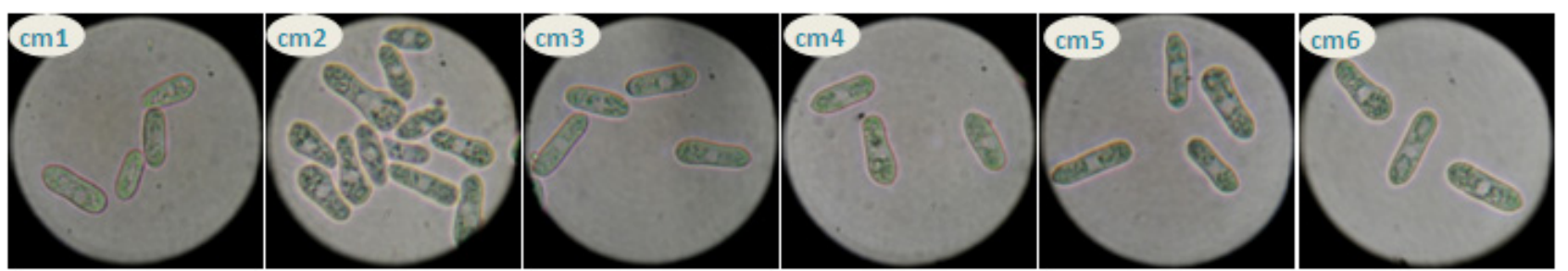

Figure 1. Shapes of spores of Colletotrichum musae isolates on CDA at 6 days after incubation at room temperature $\left(32 \pm 2^{\circ} \mathrm{C}\right)$

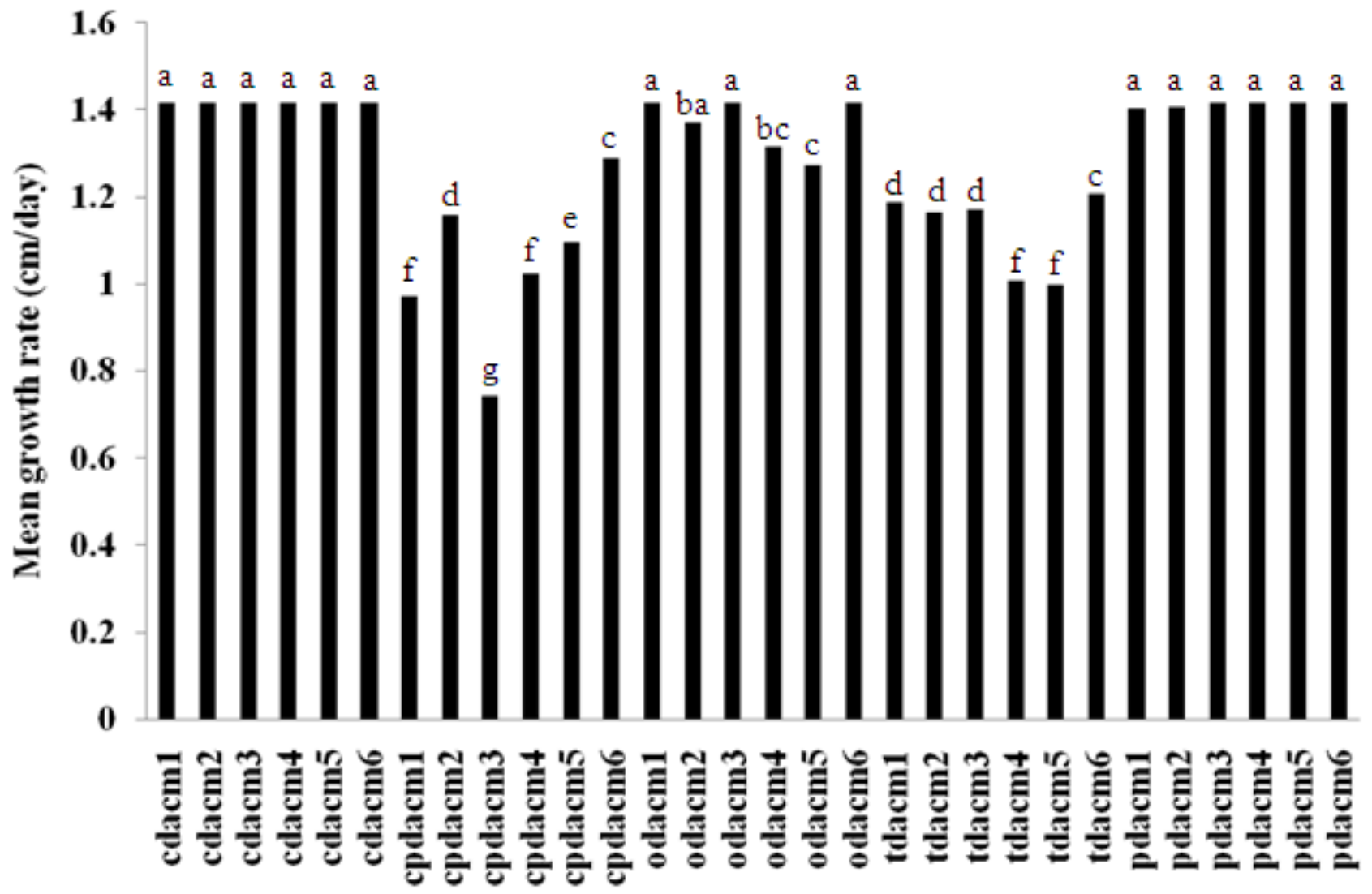

\section{Colletotrichum musae in different media}

Means followed by same letter are not significantly different by LSD at $5 \%$ level

Figure 2. Colony growth rate of Colletotrichum isolates on different media at at 6 days after incubation at room temperature $\left(32 \pm 2^{\circ} \mathrm{C}\right)$ 
Table 1. Spore dimensions of Colletotrichum musae isolates grown on CPDA medium 6 days after incubation at $32 \pm 2{ }^{\circ} \mathrm{C}$

\begin{tabular}{cccccc}
\hline \multirow{2}{*}{ Isolates } & \multicolumn{5}{c}{ Conidial Characters } \\
\cline { 2 - 6 } & $\begin{array}{c}\text { Mean Length } \\
(\mu \mathrm{m})\end{array}$ & $\begin{array}{c}\text { Mean Width } \\
(\mu \mathrm{m})\end{array}$ & $\begin{array}{c}\text { Mean Length } \\
\text { Width }\end{array}$ & Colour & Shape \\
\hline $\mathrm{cm} 1$ & $21.78^{\mathrm{a}}$ & $5.06^{\mathrm{a}}$ & $4.66^{\mathrm{a}}$ & Hyaline & Cylindrical \\
$\mathrm{cm} 2$ & $19.03^{\mathrm{b}}$ & $4.34^{\mathrm{b}}$ & $4.60^{\mathrm{ba}}$ & Hyaline & Cylindrical \\
$\mathrm{cm} 3$ & $16.50^{\mathrm{c}}$ & $4.51^{\mathrm{ba}}$ & $3.98^{\mathrm{bac}}$ & Hyaline & Cylindrica \\
$\mathrm{cm} 4$ & $15.78^{\mathrm{c}}$ & $4.62^{\mathrm{ba}}$ & $3.63^{\mathrm{c}}$ & Hyaline & Cylindrica \\
$\mathrm{cm} 5$ & $15.73^{\mathrm{c}}$ & $4.07^{\mathrm{b}}$ & $4.097^{\mathrm{bac}}$ & Hyaline & Cylindrica \\
$\mathrm{cm} 6$ & $16.67^{\mathrm{c}}$ & $4.23^{\mathrm{b}}$ & $3.95^{\mathrm{bc}}$ & Hyaline & Cylindrica \\
\hline
\end{tabular}

Means in columns followed by same letter are not significantly different by LSD at 5\% level

According to our findings CDA and PDA are the best media for Colletotrichum musae mycelial growth. Sangeetha [20] revealed that manitol followed by fructose and sucrose among the best carbon sources for the growth of $C$. gloeosporioides of mango. The fungal systematics is still based mainly on morphological criteria as observable characteristics. Hence, fungi are recognized and identified basically by their phenotypes [33]. Several other reports showed that sucrose was a better carbon source for various Colletotrichum spp [7, 18, 19,30]. Tandon and Chandra [24] reported that glucose is the best carbon source for the growth of $C$. gloeosporioides in their studies. The faster growth of fungal colonies could be an indicator that the respective isolate has the capability to colonize host tissues faster than the fungal isolates having slower growth rates. Such a positive correlation between growth rate of the fungus and virulence has been identified with fungal pathogens such as Ophiostoma ulmi and Fusarium spp. [4, 5]. Similarly, negative relationships between in vitro colony growth rate and virulence of fungal isolates have been reported $[4,5,8]$.

\section{Variation of spore morphology of Colletotrichum isolates}

Conidia were observed produced by mycelia (Figure 1). All 6 isolates produced straight, cylindrical larger and hayline with length to width ratio of about $4: 1$. Generally, conidial shape of most isolates looked very similar (Table 1). Results summarized in Table 1 demonstrated considerable variation in conidial dimensions, particularly the width. Variability of conidial length within the isolates was greatest in Colletorichum musae isolate. There was no significant different among isolates $\mathrm{cm} 3, \mathrm{~cm} 4, \mathrm{~cm} 5$ and $\mathrm{cm} 6$ in conidial length. Conidia of isolates $\mathrm{cm} 3, \mathrm{~cm} 4, \mathrm{~cm} 5$ and $\mathrm{cm} 6$ were in the range of 15.73- $16.67 \mathrm{X} 4.07-4.628 \mu \mathrm{m}$. Isolate $\mathrm{cm} 1$ was very distinct because of its size $(21.78 \times 5.06 \mu \mathrm{m})$. Such conidia were more than $2.75 \mu \mathrm{m}$ larger than that of the next biggest isolate $\mathrm{cm} 2(19.03 \times 4.34 \mu \mathrm{m})$. Lim et al. [11] reported that the conidia of $C$. musae isolates were aseptate, hyaline, ranging from $10-18 \mu \mathrm{m}$ and $5-9 \mu \mathrm{m}$. The Colletotrichum species responsible for anthracnose in banana is C. musae [16].
According to colony characters of our finding and microscopic data of spore measurements of these six isolates and after comparing data from previous studies, they could be identified as Colletotrichum musae. Our data are resembled with those reported by Sutton and Waterson [23]. The isolates tested were identified as $C$. musae by comparing their morphological characteristics with those reported by Sutton and Waterson [23]. Our findings in the study are in agreement with the results of Lim et al.[11], Photita et al.[15] and Adb-Elsalam et al.[1].

\section{Pathogenic variation}

Characteristic symptoms of anthracnose were developed by all the isolates of Colletotrichum musae on banana fruits after wound inoculation of the pathogen. Lim et al.[11] suggested that wound-inoculation with conidial suspension was the most efficient among the inoculation methods. All $C$. musae isolates were pathogenic on banana fruits variety 'Kathali'. Infections stimulate ripening of fruits, and lesions enlarge with ripening. Diameter of the anthracnose lesions varied among the six Colletotrichum musae isolates significantly $(\mathrm{p}<0.0001)$. The highest diameter of lesion of C. musae isolates were $\mathrm{cm} 4$ and $\mathrm{cm} 5$ (Figure 3). Isolates $\mathrm{cm} 1$ and $\mathrm{cm} 3$ were not significantly different in diameter of anthracnose lesion. Isolate $\mathrm{cm} 2$ gave the lowest diameter. Above observations clearly showed that banana variety 'Kathali' did not show complete resistance to any of the Colletotrichum musae isolates tested. According to definition by Taylor et al.[25] and Taylor and Ford [26], the variations of quantitative measurements on disease development provide an idea of the diverse nature of the pathogen population in terms of their aggressiveness i.e. natural variation in virulence. The level of aggressiveness of isolates of a given pathogen is also an important consideration in resistance breeding programmes and disease control management. Host genotypes with partial resistance would result in lower level of infection which eventually will decrease the inoculum amount in the field to limit the potential of epidemics [27]. 


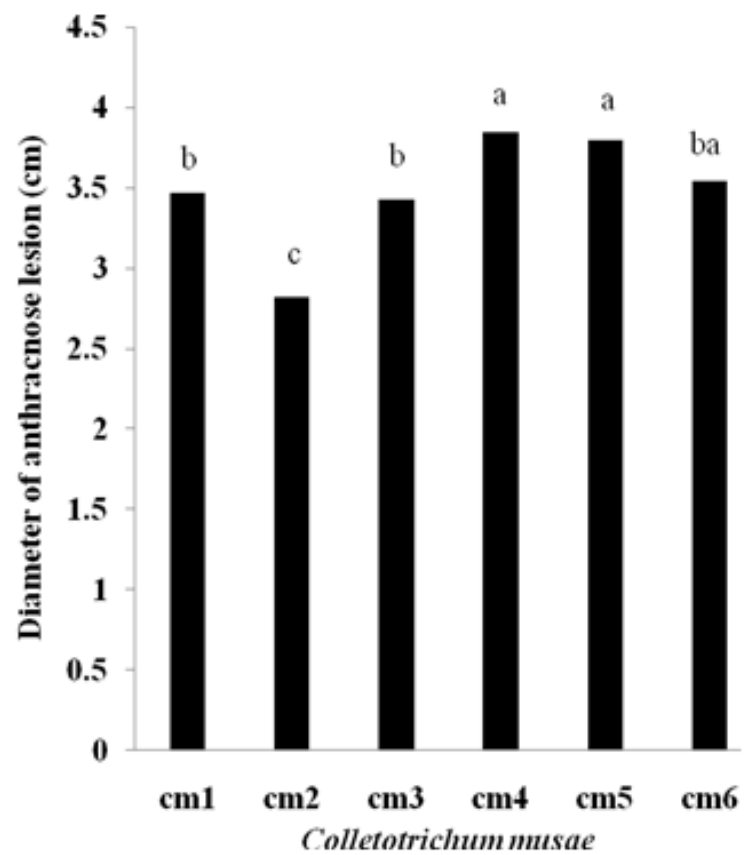

Means followed by same letter are not significantly different by LSD at $5 \%$ level

Figure 3. Mean diameter of anthracnose lesions of anthracnose symptoms by different Colletotrichum musae isolates when inoculated on banana variety Kathali

\section{Sensitivity to Fungicide and in vivo}

In vitro screening revealed that the growth of all isolates of Colletotrichum musae was completely inhibited (100\%) by Homai (Thiophanate-methyl 50\% WP + Thiram 30\% WP) and Topsin (Thiram 30\% WP) when supplemented with PDA medium at the rate of 1.8 and $1.2 \mathrm{~g} / \mathrm{L}$ respectively.

\section{Conclusions}

The present study revealed that morphological and pathogenic variations exist among isolates of Colletotrichum musae infecting banana fruits in Jaffna district of Sri Lanka. Potato and Carrot dextrose agar media supported significantly the maximum growth of isolates of C. musae.

\section{Acknowledgements}

Financial assistance by University of Jaffna, Sri Lanka is acknowledged.

\section{REFERENCES}

[1] Abd-Elsalam, K. A., Roshdy, S., Amin, O. E. and Rabani, M. (2010). First morphogenetic identification of the fungal pathogen Colletotrichum musae (Phyllachoraceae) from imported bananas in Saudi Arabia. Genetics and Molecular Research, 9 (4), 2335-2342.
[2] Adikaram, N. K. B. (1986-87). A survey of postharvest losses in some fruits and vegetables and the fungi associated with them. Ceylon Journal of Science (Biological science), 19 and 20,1-10.

[3] Bailey, J. A., Jeger, M. J. (1992). Colletotrichum: Biology, Pathology and Control. CAB International, Wallingford, UK.

[4] Brasier, C. M. and Webber, J. F. (1987). Positive correlations between in vitro growth rate and pathogenesis in Ophiostoma ulmi. Plant Pathology, 36, 462-466.

[5] Brennan, J. M., Fagan, B., Van Maanen, A., Cooke, B. M. and Doohan, F. M. (2003). Studies on in vitro growth and pathogenicity of European Fusarium fungi. European Journal of Plant Pathology, 109,577-587.

[6] Duduk, N., Ivanovic, M. and Duduk, B. (2009). Morphological, serological and molecular analyses of anthracnose-causing agent on banana fruit. Pestic Fitomedicina, 24,281-286.

[7] Durairaj, V. (1956). Growth of Colletotrichum capsici in pure culture, J. Indian Bot. Soc., 35,409-413.

[8] Irzykowska, L. and Bocianowski, J. (2008). Genetic variation, pathogenicity and mycelial growth rate differentiation between Gaeumannomyces graminis var. tritici isolates derived from winter and spring wheat. Annals of Applied Biology, 152,369-375.

[9] Ivić, D., Sever, Z. and Kuzmanovska, B. (2011). In vitro sensitivity of Fusarium graminearum, $F$. avenaceum and $F$. verticillioides to carbendazim, tebuconazole, flutriafol, metconazole and prochloraz. Pesticide and Phytomedicine, 26 (1),35-42.

[10] Latiffah, Z., Shamsiah, S., Maziah, Z. and Baharuddin, S. (2009). Characterisation of Colletotrichum Species Associated with Anthracnose of Banana. Tropical Life Sciences Research, 20(2), 119-125.

[11] Lim, J., Lim, T. H. and Cha, B. (2002). Isolation and Identification of Colletotrichum musae from Imported Bananas. Plant Pathology Journal, 18, 161-164.

[12] Meredith, D. S. (1971). Transport and storage diseases of bananas. Biology and control of Tropical Agriculture (Trinidad), 48(1), 35-50.

[13] Nazriya, M. N. F., De Costa, D. M. and Azhaar, A. S. (2007). Genomic variation of Colletotrichum musae morphotypes infecting banana varieties of Sri Lanka. Proc Peradeniya Univ Res Sessions, 12, 1-2.

[14] Perera, N. and Karunaratne, A. M. (1995). A study of some peel characteristic of five local varieties of banana and non-pesticidal chemicals that promote resistant to postharvest diseases. Proceedings Sri Lanka Association for the Advancement of science, 51(1), 68-70.

[15] Photita, W., Taylor, P. W. J., Ford, R. and Hyde, K. D. (2005). Morphological and molecular characterization of Colletotrichum species from herbaceous plants in Thailand. Fungal Divers, 18, 117-133.

[16] Ploetz, R. C., Thomas, J. E. and Slabaugh, W. R. (2003). Diseases of banana and plantain. In: PLOETZ, R.C. (Ed.). Diseases of tropical fruit crops Florida. University of Florida (UFAS), 96-98. 
[17] Prusky, D. and Plumbley, R. A. (1992). Quiescent infections of Colletotrichum in tropical and subtropical fruits. In J A Bailey and M J Jeger (eds.) Colletotrichum: Biology, pathology and control. Wallingford, UK: CAB International, 289-307.

[18] Ramakrishnan, T. S. (1941). Studies in the genus Colleto-trichum: III. Physiological studies on Colleto-trichum falcatum. Proc. Indian Acad. Sci., India (B, 14, 395-411.

[19] Reddy, B. P. N. (2000). Studies on morphological, cultural, and pathogenic variations among the isolates of Col-letotrichum gloeosporioides (Penz.) Penz. and Sacc. of some subtropical fruits. M.Sc. Thesis, Univ. Ag-ric. Sci., Bangalore, 69.

[20] Sangeetha, C. G. (2003). Studies on anthracnose of mango caused by Colletotrichum gloeosporioides (Penz.) Penz. and Sacc. PhD Thesis, Univ. Agric. Sci., Bangalore, 77-156.

[21] Stover, R. H. and Simmonds, N. W. (1987). Diseases and disorders. In: Bananas, Longman, 281-323.

[22] Sutton, B. C. (1992). The genus Glomerella and its anamorph Colletotrichum. In: Colletotrichum :biology, pathology and control (Eds. J.A. Bailey and M.J. Jeger). CAB International, Wallingford, 1-26.

[23] Sutton, B. C. and Waterston, N. W. (1970). Colletotrichum musae. CMI Description of Pathogenic Fungi and Bacteria. Eastern Press, London, 222.

[24] Tandon, R. N. and Chandra, S. (1962). The nutrition of Colle-totrichum gloeosporioides (Penz.) Penz. and Sacc.. Mycopathologica, 18, 213-214.

[25] Taylor, P. W. J., Mongkolporn, O., Than, P. P., Montri, P., Ranathunge, N., Kanchanaudonkarn, C., Ford, R., Pongsupasamit, S. and Hyde, K. D. (2007). Pathotypes of Colletotrichum spp. Infecting Chilli Peppers and Mecha-nisms of Resistance. In: Oh, D.G., Kim, K.T. (Eds.), Abstracts of the First International Symposium on Chilli
Anthracnose. National Horticultural Research Institute, Rural Development of Administration, Republic of Korea, 29.

[26] Taylor, P. W. J. and Ford, R. (2007). Diagnostics, Genetics diversity and pathogenic variation of ascochyta blight of cool season food and feed legumes. European Journal of Plant Pathology, 127-133.

[27] Than, P. P., Jeewon, R., Hyde, K. D., Pongsupasamit, S., Mongkolporn, O. and Taylor, P. W. J. (2008). Characterization and pathogenicity of Colletotrichum species associated with anthracnose disease on chilli (Capsicum spp.) in Thailand. Plant Pathology, 57(3), 562-572.

[28] Thangamani, P., Kuppusamy, P., Peeran, M. F., Kathikeyan, G. and Thiruvengadam, R. (2011). Morphological and Physiological Characterization of Colletotrichum musae the Causal Organism of Banana Anthracnose. World Journal of Agricultural Sciences, 7 (6), 743-754.

[29] Thompson, A. K. and Burden, O. J. (1995). Harvesting and fruit care. In: Bananas and plantains, S. Gowen, Chapman \& Hall, 403-433.

[30] Verma, M. L. (1979). Effect of sucrose concentration on growth and sporulation of three species of Colleto-trichum pathogenic on chilies. Indian J. Mycol. Pl. Pathol., 9, 130-131.

[31] Wijesundera, R. L. C. (1994). Variation in Colletotrichum gloeosporioides isolates from banana. Journal of National Science Council Sri Lanka, 22, 145-150.

[32] Zhae, S. and Simon, F. S. (2006). Effect of culture media, temperature, $\mathrm{pH}$ and bio-herbicidal efficacy of Phoma exigua, a potential biological control for salal (Gaultheria shallon). Biocontrol Sci. Technol., 6, 1043-1055.

[33] Zain, M. E., Razak, A. A., El-Sheikh, H. H., Soliman, H. G. and Khalil, A. M. (2009). Influence of growth medium on diagnostic characters of Aspergillus and Penicillium species. African Journal of Microbiology Research, 3(5), 280-286. 